\title{
LEVEL OF HEPCIDINE IN PATIENTS WITH ANKYLOSING SPONDYLITIS, ASSOCIATION WITH ANEMIA AND THE SEVERITY OF THE DISEASE
}

DOI: 10.36740/WLek202008121

\author{
Sergii V. Shevchuk ${ }^{1,2}$, Oksana V. Zviahina ${ }^{1}$, Inna P. Kuvikova ${ }^{1,2}$, Iuliia S. Segeda ${ }^{1,2}$ \\ 'NATIONAL PIROGOV MEMORIAL MEDICAL UNIVERSITY, VINNYTSIA, UKRAINE \\ ${ }^{2} S$ CIENTIFIC AND RESEARCH INSTITUTE OF DISABILITY REHABILITATION OF NATIONAL PIROGOV MEMORIAL MEDICAL UNIVERSITY, VINNYTSIA, \\ UKRAINE
}

\begin{abstract}
The aim: To assess the level of hepcidin in patients with AS, to determine its connection to the disease and various forms of anemia.

Materials and methods: 118 patients with ankylosing spondylitis were examined and hematological, biochemical, immunologic indicators of the general parameters of hematopoiesis and ferrokinetics, plasma levels of CRP, IL-6 and hepcidin were determined.

Results: It was found that high levels of hepcidin are found in $25 \%$ of patients with AS, $50 \%$ are limiting and only $25 \%$ are optimal. The serum levels of hepcidin in patients with AS are independent of the age, sex, and duration of the disease, but are closely associated with the activity (ESR, CRP, IL-6, BASDAl, and ASDAS levels) of the disease. Close pathogenetic connection of hepcidin with the formation of anemic syndrome was established. Patients with ACD were characterized by the highest levels of hepcidin. Conclusions: Hepcidin plays an important role in the pathogenesis of ACD in patients with AS and can be used as a diagnostic marker for differential diagnosis.
\end{abstract}

KEY WORDS: ankylosing spondylitis, anemic syndrome, hepcidin, IL-6, CRP , ASDAS, BASDAI

Wiad Lek. 2020;73(8):1700-1706

\section{INTRODUCTION}

In patients with ankylosing spondylitis (AS), anemia is found in $18.5-45.8 \%[1,2,3,4,5,6,7]$. Most often, anemia in patients with AS is represented by anemia of chronic disease (ACD), the frequency of which according to various studies is $33.3 \%-78.72 \%$, however, iron deficiency anemia (IDA), caused by gastrointestinal blood loss and associated with intake of drugs for the treatment of AS, takes place at $21.28 \%-66.7 \%$, and, can coexist with ACD $[3,6]$. The leading causes of ACD is shortening the life of red blood cells, iron metabolism, inhibition of the synthesis of erythropoietin and productions of cytokines, which affects erythropoiesis [8].

Recent evidence suggests that hepcidin is a major mediator of anemia and plays a central role in both homeostasis and metabolism of iron and may play a key role in the pathogenesis of ACD due to its effect on iron metabolism and its close relationship with cytokines and inflammation [9]. The connection between hepcidin, IL- 6 and iron metabolism was first demonstrated by S. Pigeon et al. [10]. He showed that it stimulates IL-6 expression of acute phase protein hepcidin by hepatocytes, which in its turn inhibits iron absorption in the duodenum. Inflammation triggers the increase of hepcidin level that reduces iron absorption in the intestine and the release of iron from macrophages by biochemic mechanism known as hepcidin-ferroportin interaction [11]. That is, the total content of iron in the body is normal, but it is not enough for effective erythropoiesis [12] .
In case of pure iron deficiency anemia (IDA), hepcidin concentration in serum and urine is significantly reduced. Even in the absence of anemia, hepcidin is a sensitive indicator of iron deficiency. Moreover, compared to hematocrit and hemoglobin, hepcidin reduction is an early marker of iron deficiency, along with transferrin saturation and ferritin decrease [13]. Patients with inflammatory disorders and concomitant iron deficiency typically have lower levels of hepcidin than those who are "pure" ACD [14] .

So hepcidin is a promising tool that should be added to the current list of diagnostic tests status of iron, particularly in IDA because it has the potential for differential diagnosis of ACD and IDA and inform the patient's ability to respond to therapy with oral iron [8]. In addition, there practically no data on age and sex characteristics of hepcidin concentration in blood serum, as well as its association with other factors that complicate the course of the disease.

\section{THE AIM}

The aim of the study is to evaluate the level of hepcidin in patients with AS, to determine its correlation with the disease and various forms of anemia.

\section{MATERIALS AND METHODS}

The study involved 118 patients with AS. The diagnosis of AS was made in accordance with modified New York criteria 
Table I. Percentile analysis of serum hepcidin content in almost healthy persons and patients with AS

\begin{tabular}{ccccccccc}
\hline \multirow{2}{*}{ Groups } & Median & \multicolumn{7}{c}{ Hepcidin, $\mathbf{n g} / \mathbf{m l}$} \\
\cline { 3 - 8 } & & $\mathbf{P}_{\mathbf{5}}$ & $\mathbf{P}_{\mathbf{1 0}}$ & $\mathbf{P}_{\mathbf{2 5}}$ & $\mathbf{P}_{\mathbf{7 5}}$ & $\mathbf{P}_{\mathbf{9 0}}$ & $\mathbf{P}_{\mathbf{9 5}}$ \\
\hline Control, $\mathrm{n}=26$ & 30,0 & 17,97 & 23,95 & 25,25 & 35 & 38,1 & 38,8 \\
\hline Patients with AS, $\mathrm{n}=76$ & 37,2 & 14,62 & 18,75 & 27 & 49,15 & 74,14 & 87,38 \\
\hline
\end{tabular}

Table II. Ranging of hepcidin levels in patients with AS and its relationship with age, sex and disease duration

\begin{tabular}{|c|c|c|c|c|}
\hline \multirow{3}{*}{ Groups } & \multirow[t]{2}{*}{ Hepcidin, ng / ml } & \multicolumn{3}{|c|}{$\begin{array}{l}\text { Frequency of detection of hepcidin level, } \\
\qquad \mathbf{n}(\%)\end{array}$} \\
\hline & & optimal & extremely high & high \\
\hline & $M \pm m$ & $<27 \mathrm{ng} / \mathrm{ml}$ & $27-49 \mathrm{ng} / \mathrm{ml}$ & $>49 \mathrm{ng} / \mathrm{ml}$ \\
\hline Control, $n=26$ & $30,10 \pm 1,36$ & $8(30,8 \%)$ & $18(69,2 \%)$ & $0(0,0 \%)$ \\
\hline Patients with AS, $n=76$ & $42,07 \pm 2.51 *$ & $19(25 \%)$ & $38(50 \%)^{*}$ & $19(25 \%)$ \\
\hline \multicolumn{5}{|c|}{ Including: } \\
\hline Females on AS, $n=13$ & $51,31 \pm 7,26$ & $3(23,1 \%)$ & $4(30,8 \%)$ & $6(46,1 \%)$ \\
\hline Males on AS, $n=63$ & $40,16 \pm 2,60$ & $16(25,4 \%)$ & $34(54 \%)$ & $13(20,6 \%)$ \\
\hline \multicolumn{5}{|c|}{ Communication with age } \\
\hline Ages $19-35, n=18$ & $39,06 \pm 4,69$ & $5(27,8 \%)$ & $9(50 \%)$ & $4(22,2 \%)$ \\
\hline Ages $35-55, n=48$ & $43,85 \pm 3,27$ & $12(25 \%)$ & $22(45,8 \%)$ & $14(29,2 \%)$ \\
\hline Ages $55-75, n=10$ & $38,92 \pm 7,20$ & $2(20 \%)$ & $7(70 \%)$ & $1(10 \%)$ \\
\hline \multicolumn{5}{|c|}{ Connection with the duration of the disease } \\
\hline Up to 5 years, $n=33$ & $42,25 \pm 3,88$ & $10(30,3 \%)$ & $13(39,4 \%)$ & $10(30,3 \%)$ \\
\hline $5-10$ years, $n=30$ & $44,61 \pm 4,11$ & $5(16,7 \%)$ & $16(53,3 \%)$ & $9(30 \%)$ \\
\hline$>10$ years, $n=13$ & $35,74 \pm 5,53$ & $4(30,8 \%)$ & $8(61,5 \%)$ & $1(7,7 \%)$ \\
\hline
\end{tabular}

Notes: * - significance of differences with the control group, $\mathrm{p}<0,05$; hepcidin level study was conducted in 76 (64.4\%) patients.

Table III. The content of markers of inflammation in the serum of patients with AS $(n=76)$ depending on the level of hepcidin

\begin{tabular}{|c|c|c|c|c|}
\hline \multicolumn{2}{|r|}{ Characterization of groups by hepcidin level } & $\begin{array}{l}\text { Optimal (hepcidin } \\
\begin{array}{c}<27 \mathrm{ng} / \mathrm{ml}), \\
\mathrm{n}=19\end{array}\end{array}$ & $\begin{array}{l}\text { Extremely high } \\
\text { (hepcidin } \\
\begin{array}{c}\text { 27-49 } \mathrm{ng} / \mathrm{ml} \text { ), } \\
\mathrm{n}=\mathbf{3 8}\end{array}\end{array}$ & $\begin{array}{c}\text { High } \\
\text { (hepcidin } \\
>49 \mathrm{ng} / \mathrm{ml} \text { ), } \\
\mathrm{n}=19\end{array}$ \\
\hline \multirow{3}{*}{ CRP, ng } & $M \pm m$ & $9,33 \pm 0,87$ & $14,15 \pm 1,47^{*}$ & $14,44 \pm 1,46^{*}$ \\
\hline & The proportion of patients with CRP $>18 \mathrm{ng} / \mathrm{l}, \mathrm{n}(\%)$ & $1(5,3 \%)$ & $11(28,9 \%)^{*}$ & $7(36,8 \%)^{*}$ \\
\hline & Correlation coefficient & & $r=0,30 ; p<0,01$ & \\
\hline \multirow{3}{*}{$\begin{array}{c}\mathrm{IL}-6, \\
\mathrm{~g} / \mathrm{ml}\end{array}$} & $M \pm m$ & $22,26 \pm 3,02$ & $24,75 \pm 1,85$ & $28,23 \pm 2,31$ \\
\hline & The proportion of patients with IL- $6>32,45 \mathrm{~g} / \mathrm{ml}, \mathrm{n}(\%)$ & $0(0,0 \%)$ & $3(7,9 \%)^{*}$ & $7(36,8 \%)^{*}$ \\
\hline & Correlation coefficient & & $r=0,36 ; p<0,01$ & \\
\hline \multirow{3}{*}{$\begin{array}{c}\text { ESR, } \\
\mathrm{mm} / \mathrm{h}\end{array}$} & $M \pm m$ & $21,61 \pm 1,73$ & $25,42 \pm 2,04$ & $34,88 \pm 4,36^{*}$ \\
\hline & The proportion of patients with ESR $>45 \mathrm{~mm} / \mathrm{h}, \mathrm{n}(\%)$ & $0(0,0 \%)$ & $3(7,9 \%)^{*}$ & $3(15,8 \%)^{*}$ \\
\hline & Correlation coefficient & & $r=0,38 ; p<0,01$ & \\
\hline
\end{tabular}

Notes: * significant differences for the group with the lowest hepcidin, $p<0.05$

for the diagnosis of AS [15]. Among the patients studied were $102(86.4 \%)$ males and $16(13.6 \%)$ females. The average age of the examined patients was within $43.67 \pm 0.97$ years.
Anemic syndrome was diagnosed in 34 (28.8\%) patients as recommended by the world health organization (WHO) [16]. In $84(71.2 \%)$ surveyed the central form of AS was 
Table IV. Relationship of inflammatory process activity in BASDAI, ASDAS and VAS questionnaires with hepcidin levels in AS patients ( $n=76$ )

\begin{tabular}{|c|c|c|c|c|}
\hline \multicolumn{2}{|c|}{ Characterization of groups by hepcidin level } & $\begin{array}{c}\begin{array}{c}\text { Optimal } \\
\text { (hepcidin } \\
<27 \mathrm{ng} / \mathrm{ml} \text { ), } \\
\mathrm{n}=19\end{array} \\
\end{array}$ & $\begin{array}{l}\text { Extremely high } \\
\text { (hepcidin } \\
\begin{array}{c}27-49 \mathrm{ng} / \mathrm{ml} \text { ), } \\
\mathrm{n}=38\end{array}\end{array}$ & $\begin{array}{c}\text { High } \\
\text { (hepcidin } \\
>49 \mathrm{ng} / \mathrm{ml} \text { ), } \\
\mathrm{n}=19\end{array}$ \\
\hline \multirow[b]{2}{*}{ BASDAI, bales } & $\mathrm{M} \pm \mathrm{m}$ & $5,24 \pm 0,28$ & $5,84 \pm 0,21$ & $6,81 \pm 0,38^{*}$ \\
\hline & $\begin{array}{c}\text { The proportion of patients with } \\
\text { BASDAI > } 7 \text { bales, } \mathrm{n}(\%)\end{array}$ & $1(5,3 \%)$ & $7(18,4 \%)$ & $9(47,4 \%)^{*}$ \\
\hline \multirow[b]{2}{*}{ ASDAS, bales } & $\mathrm{M} \pm \mathrm{m}$ & $3,65 \pm 0,16$ & $3,91 \pm 0,10$ & $4,27 \pm 0,13^{*}$ \\
\hline & $\begin{array}{c}\text { The proportion of patients with } \\
\text { ASDAS }>3,2 \text { bales, } n(\%)\end{array}$ & $13(68,4 \%)$ & $33(86,8 \%)$ & $18(94,7 \%)^{*}$ \\
\hline \multirow[b]{2}{*}{ VAS, bales } & $M \pm m$ & $7,63 \pm 0,28$ & $7,58 \pm 0,22$ & $7,84 \pm 0,34$ \\
\hline & $\begin{array}{l}\text { The proportion of patients with } \\
\text { VAS }>8 \text { bales, } n(\%)\end{array}$ & $9(47,4 \%)$ & $18(47,4 \%)$ & $11(57,9 \%)$ \\
\hline
\end{tabular}

Notes: ${ }^{*}$ significant differences for the group with the lowest hepcidin, $p<0.05$

Table V. The content of hepcidin in serum and its ranking in patients with AS with anemia

\begin{tabular}{|c|c|c|c|c|}
\hline \multirow{3}{*}{ Groups } & \multirow[t]{2}{*}{ Hepcidin, ng / ml } & \multicolumn{3}{|c|}{$\begin{array}{l}\text { Frequency of detection of hepcidin level, } \\
\qquad \mathbf{n}(\%)\end{array}$} \\
\hline & & optimal & extremely high & high \\
\hline & $M \pm m$ & $<27 \mathrm{ng} / \mathrm{ml}$ & 27-49 ng / ml & $>49 \mathrm{ng} / \mathrm{ml}$ \\
\hline Control, $n=26$ & $30,10 \pm 1,36$ & $8(30,8 \%)$ & $18(69,2 \%)$ & $0(0,0 \%)$ \\
\hline Patients without anemia, $\mathrm{n}=47$ & $36,08 \pm 2,57$ & $14(29,8 \%)$ & $27(57,4 \%)$ & $6(12,8 \%)$ \\
\hline Patients with anemia, n=29 & $51,77 \pm 4,62 * \&$ & $5(17,2 \%)$ & $11(38 \%)^{*}$ & $13(44,8 \%)$ \\
\hline \multicolumn{5}{|c|}{ Including: } \\
\hline IDA, $n=7$ & $35,84 \pm 7,50$ & $2(28,6 \%)$ & $4(57,1 \%)$ & $1(14,3 \%)$ \\
\hline ACD with iron deficiency, $n=6$ & $48,53 \pm 9,50$ & $2(33,3 \%)$ & $1(16,7 \%)$ & $3(50 \%)$ \\
\hline$A C D, n=15$ & $62,78 \pm 5,94 \#$ & $0(0,0 \%)$ & $5(33,3 \%)$ & 10(66,6\%)\# \\
\hline \multicolumn{5}{|c|}{ Including: } \\
\hline Anemia 1st degree, $n=23$ & $53,98 \pm 5,30$ & $4(17,4 \%)$ & $7(30,4 \%)$ & $12(52,2 \%)$ \\
\hline Anemia 2nd degree, $n=6$ & $43,32 \pm 9,26$ & $1(16,7 \%)$ & $3(50 \%)$ & $2(33,3 \%)$ \\
\hline \multicolumn{5}{|c|}{ Including anemia: } \\
\hline Normocytic, $n=17$ & $54,01 \pm 5,67$ & $2(11,8 \%)$ & $6(35,3 \%)$ & $9(52,9 \%)$ \\
\hline Microcytic, $n=8$ & $48,79 \pm 10,23$ & $2(25 \%)$ & $3(37,5 \%)$ & $3(37,5 \%)$ \\
\hline Macrocytic, n=4 & $48,25 \pm 14,46$ & $1(25 \%)$ & $1(25 \%)$ & $2(50 \%)$ \\
\hline
\end{tabular}

Note. * - significant differences in control group, $p<0.05 ; \&$ - significant differences in the group of patients without anemia, $p<0.05$; \# - significant differences in the group of patients with IDA, $p<0.05$

registered, in $34(28.8 \%)$ it was peripheral. All patients were divided into three main groups: a group of patients with AS without anemic syndrome, consisting of 84 patients, a group of patients with AS with anemic syndrome (34 patients), and a control group (26 persons), which included practically healthy people without systemic inflammatory diseases and anemia, representative of age and gender. The average age of the patients examined was within $43.67 \pm 0.97$ years and did not differ significantly between the patient groups.

Each patient was tested for hemoglobin (HB), erythrocytes, MCV, serum iron, total iron binding capacity (TIBC), serum ferritin, transferrin saturation (TS), and soluble transferrin receptors (sTfR). All laboratory parameters were deter- mined by conventional methods. Hematologic parameters were determined on the ERMA PCE-210 device (Japan), biochemical parameters were determined on the hardware (Humalyzer 2000 biochemical analyzer) and the enzyme immunoassay using Stat Fax 303 / Plus using standard reagents. The content of Heps 25 in serum was determined by enzyme immunoassay according to the "Human Hepsidin25 ELISA Kit" (Elabscience, USA) kit according to the instructions of the manufacturer. To evaluate the activity of the inflammatory process of AS in the serum, he content of C-reactive protein (CRP) and IL-6 enzyme immunoassay were quantified.

To determine disease activity, ASDAS (Ankylosing Spondylitis Disease Activity Score) [18] and BASDAI 
Table VI. Relation of hepcidin levels with hematopoiesis and ferrokinetics in patients with $A S(M \pm m)$

\begin{tabular}{|c|c|c|c|}
\hline \multirow[b]{2}{*}{ Indexes } & \multicolumn{3}{|c|}{ Hepcidin, ng / ml } \\
\hline & optimal & extremely high & high \\
\hline & $<27 \mathrm{ng} / \mathrm{ml}$ & $27-49 \mathrm{ng} / \mathrm{ml}$ & $>49 \mathrm{ng} / \mathrm{ml}$ \\
\hline \multicolumn{4}{|c|}{ Patients with AS without anemia, $n=47$} \\
\hline Number of observations (n,\%) & $14(29,8 \%)$ & $27(57,4 \%)^{@}$ & $6(12,8 \%)$ \\
\hline Hemoglobin, g / I & $134,14 \pm 3,00$ & $132,07 \pm 2,09$ & $131,50 \pm 4,75$ \\
\hline Erythrocytes, $10^{12} / \mathrm{I}$ & $4,55 \pm 0,10$ & $4,43 \pm 0,08$ & $4,37 \pm 0,21$ \\
\hline MCV, fl & $82,03 \pm 2,83$ & $84,70 \pm 1,86$ & $83,56 \pm 4,82$ \\
\hline Iron, $\mu \mathrm{mol} / \mathrm{I}$ & $14,85 \pm 0,79$ & $12,55 \pm 0,65$ & $14,65 \pm 0,97$ \\
\hline $\mathrm{TIBC}, \mu \mathrm{mol} / \mathrm{I}$ & $58,08 \pm 0,84$ & $53,74 \pm 1,09 *$ & $56,22 \pm 2,33$ \\
\hline $\mathrm{TS}, \%$ & $25,57 \pm 1,35$ & $23,05 \pm 1,03$ & $26,53 \pm 2,80$ \\
\hline Ferritin, mcg / I & $22,49 \pm 1,76$ & $26,88 \pm 2,45$ & $19,00 \pm 1,59^{*}$ \\
\hline sTfR, mg / I & $3,03 \pm 0,16$ & $3,07 \pm 0,20$ & $3,91 \pm 0,54$ \\
\hline \multicolumn{4}{|c|}{ Patients with AS with anemic syndrome, $n=29$} \\
\hline Number of observations (n,\%) & $5(17,2 \%)$ & $11(38 \%)$ & $13(44,8 \%)$ \\
\hline Hemoglobin, g / I & $101,00 \pm 6,21$ & $101,09 \pm 3,72$ & $99,31 \pm 2,96$ \\
\hline Erythrocytes, $10^{12} / \mathrm{I}$ & $3,58 \pm 0,23$ & $3,64 \pm 0,12$ & $3,57 \pm 0,10$ \\
\hline $\mathrm{MCV}, \mathrm{fl}$ & $82,19 \pm 8,39$ & $86,26 \pm 3,52$ & $91,92 \pm 2,71$ \\
\hline Iron, $\mu \mathrm{mol} / \mathrm{I}$ & $8,76 \pm 0,39$ & $10,16 \pm 0,47^{*}$ & $10,87 \pm 0,39 *$ \\
\hline TIBC, $\mu \mathrm{mol} / /$ & $59,56 \pm 2,42$ & $64,55 \pm 4,34$ & $56,87 \pm 1,61$ \\
\hline $\mathrm{TS}, \%$ & $15,52 \pm 1,52$ & $16,80 \pm 1,62$ & $19,33 \pm 0,89^{*}$ \\
\hline Ferritin, mcg / I & $22,10 \pm 1,76$ & $26,50 \pm 3,27$ & $34,03 \pm 3,48^{*}$ \\
\hline sTfR, mg / I & $6,02 \pm 0,71$ & $5,30 \pm 0,92$ & $4,88 \pm 0,64$ \\
\hline
\end{tabular}

Note. ${ }^{*}$ - significant differences for the group with the lowest hepcidin index, $\mathrm{p}<0.05$; @ - significant differences with respect to the group with extremely high levels of hepcidin, $\mathrm{p}<0,05$

(Bath Ankylosing Spondylitis Disease Activity Index) [19] questionnaires were used.

Statistical processing of the obtained results was performed using the statistical software package "Microsoft Office Excel 2007" with determination of arithmetic mean, quadratic deviation and mean error of arithmetic mean. The results are presented as $\mathrm{M} \pm \mathrm{m}$. The reliability of the results was assessed using the Student's t-test (the differences were considered with $\mathrm{p}<0.05$ ) and the Fischer's test. The correlation of traits was determined by calculating the correlation coefficient ( $\mathrm{r}$ ).

\section{RESULTS}

Analysis of hepcidin content in serum showed that the control group and patients with AS significantly differ in this indicator.

When conducting a percentile comparison (Tabl. I) it was found that the level of hepcidin was in the range of $17.97-38.8 \mathrm{ng} / \mathrm{ml}\left(\mathrm{P}_{5}-\mathrm{P}_{95}\right)$ in $95 \%$ of the control group, and in patients with AS in 95\% was in the range of 14.62 $-87.38 \mathrm{ng} / \mathrm{ml}$. Inasmuch as there are no clear criteria for grading hepcidin levels in the literature, we have chosen indicators that approach the $\mathrm{P}_{25}$ and $\mathrm{P}_{75}$ groups of AS patients for further analysis. We considered the optimal level of hepcidin up to $27 \mathrm{ng} / \mathrm{ml}\left(<\mathrm{P}_{25}\right)$, extremely high - 27 - $49 \mathrm{ng} / \mathrm{ml}\left(\mathrm{P}_{25}-\mathrm{P}_{75}\right)$, high - above $49 \mathrm{ng} / \mathrm{ml}\left(>\mathrm{P}_{75}\right)$. In assessing the results of analysis percentiles hepcidin content in the serum of healthy individuals and patients with AS revealed that the hepcidin $\mathrm{P}_{95}$ level in AS patients was 2.3 times higher than the $\mathrm{P}_{95}$ control group.

When comparing the average level of hepcidin in patients with AS $(42.07 \pm 2.51 \mathrm{ng} / \mathrm{ml})$ and people in the control group $(30.10 \pm 1.36 \mathrm{ng} / \mathrm{ml})$, it was found that in the main group, its average levels are higher by $28.5 \%$ (Tabl. II). In the AS group, 50\% showed extremely high levels of hepcidin and $25 \%$ had normal and high levels of hepcidin. In the group of healthy subjects, there were no high levels of hepcidin, $69.2 \%$ had high levels and 30.8 were optimal. Analysis of gender peculiarities in hepcidin levels showed that the latter was $21.7 \%$ higher in women than in men. No significant difference was established in the mean value and structural division of patients by hepcidin level in different age groups of patients. Regarding the duration of the disease, there were also no significant differences between the groups with the shortest disease duration comparing to the persons with the longest disease experience. In particular, in the groups of up to 5 years and 5-10 years the level of hepcidin was in the range of $42.25 \pm 3.88 \mathrm{ng} / \mathrm{ml}$ 
and $44.61 \pm 4.11 \mathrm{ng} / \mathrm{ml}$, which is $15.4 \%$ and $19.9 \%$ higher, respectively, than in the group over 10 years.

The study found (Tabl. III) that concurrently with the increase of hepcidin levels, the inflammation markers concentration (ESR, CRP, IL-6) increased in serum. Thus, significant differences were observed in the levels of markers of the inflammatory process between groups with extremely high and optimal levels of hepcidin. Furthermore, in the high hepcidin group, the mean values as well as the proportion of individuals with high levels of ESR, CRP and IL-6 were even more striking. In particular, in the group with high levels of hepcidin, compared to its optimal level, mean ESR, CRP and IL-6 values were 21\% -38\% higher. The largest number of patients with high levels of CRP, IL- 6 and ESR were detected in the group with high hepcidin. The close connection between inflammatory process markers on the one hand and hepcidin levels on the other was confirmed by correlation analysis.

In the next part of our study we evaluated the extent to which the disease activity according to BASDAI, ASDAS and VAS questionnaires changed depending on hepcidin levels (Tabl. IV). It was found that with increasing hepcidin concentration the proportion of patients with high levels of BASDAI and ASDAS increased. In particular, the proportion of individuals with high BASDAI and ASDAS values in the high hepcidin group compared to the optimal values was 1.38 , and 8.3 times higher, respectively. There are no significant differences depending on VAS scale and hepcidin levels.

As hepcidin plays a key role in the metabolism of iron, we rated its level in the patient groups with and without anemia (Tabl. V) .

It was found that in patients without anemia $(36.08 \pm 2.57$ $\mathrm{ng} / \mathrm{ml}$ ) the average hepcidin value significantly differed from the group of patients with anemia $(51.77 \pm 4.62 \mathrm{ng} /$ $\mathrm{ml})$. The proportion of people with high hepcidin among people with anemia appeared to be 3.5 times higher than in patients without anemia. The lowest level of hepcidin was found in persons with signs of IDA $(35.84 \pm 7.50 \mathrm{ng} / \mathrm{ml})$, and the highest $(62.78 \pm 5.94 \mathrm{ng} / \mathrm{ml})$ in groups and patients with ACD. ACD group with functional iron deficiency took an intermediate position in terms of hepcidin levels $(48.53 \pm 9.50 \mathrm{ng} / \mathrm{ml})$.

Hepcidin analysis depending on the degree of anemia showed that people with mild anemia degree had 23\% higher hepcidin level than patients with an average degree of anemia. We believe, however, that the vast majority of patients with grade 2 anemia had the actual IDA, which was characterized by lower levels of hepcidin, and patients with grade 1 anemia had signs of ACD and ACD with functional deficiency of iron.

The same differences are observed in the comparative analysis of groups by cytometric characteristics. The highest levels of hepcidin and the highest number of persons with high levels of the latter were recorded in the groups with normocytic (52.9\%) and macrocytic anemia (50\%), compared to $37.5 \%$ in the group with microcytosis, since microcytic changes of erythrocytes are more characteristic of IDA, while ACD and ACD with functional deficiency of iron are characterized by normocytosis and macrocytosis.

We have also conducted an analysis of levels of hepcidin with hematopoiesis and ferrokinetics markers in AS patients with anemia and without it (Tabl. VI). In the group of patients without anemia we found no association of hepcidin with red blood and ferrokinetics.

Whereas, in persons with anemia, the association of hepcidin with serum iron, the transferrin saturation with iron and ferritin was clearly traced. Thus, in the group with the optimal level of hepcidin, the level of iron $(8.76 \pm 0.39$ $\mu \mathrm{mol} / \mathrm{l}$ ) was the lowest. Significantly higher levels of this indicator were in people with very high and highest hepcidin. The same tendency is characteristic of TS, the lowest of which was in the group with the optimal level of hepcidin $(15.52 \pm 1.52 \%)$, intermediate $(16.80 \pm 1.62 \%)$ in persons with extremely high, and highest $(19.33 \pm 0.89 \%)$ in those with the high level. With regard to soluble transferrin receptors, with the growth of hepcidin their level was decreasing from $6.02 \pm 0.71 \mathrm{mg} / \mathrm{l}$ in the group with the optimum hepcidin level to $4.88 \pm 0.64 \mathrm{mg} / \mathrm{l}$ in the group with high hepcidin. Ferritin, like hepcidin, responded to inflammation by increasing its amount. It was $16.6 \%$ higher in the group with extremely high levels of hepcidin and $35 \%$ higher in the group with high levels of hepcidin compared to the group with its optimal value.

\section{DISCUSSION}

Thus, evaluation of hepcidin levels in patients with AS showed that their levels are significantly higher in patients of the main group than in healthy individuals. In the AS group, only $25 \%$ of those surveyed had normal values, $50 \%$ had extremely high and $25 \%$ had high values. In the group of healthy subjects, high levels of hepcidin were not registered, in $69.2 \%$ were extremely high levels and in $30.8 \%$ were optimal. The data obtained by us is consistent with the results of the Turkish population of AS patients [8] , according to which serum levels of hepcidin in AS patients were 1.6 times higher than in control subjects $(73.77 \pm 15.36 \mathrm{mg} / \mathrm{dl}$, against $45.82 \pm 10.71 \mathrm{mg} / \mathrm{dL}, \mathrm{p}<0.05$, respectively).

The study did not reveal any gender differences in hepcidin levels, as well as the age and duration of the disease.

One of the unfavorable pathogenetic factors of hepcidin synthesis disorders is the systemic inflammatory process. We have shown that the increase in serum levels of hepcidin in patients with AS is associated with the severity of organ lesions and the activity of the inflammatory process. Thus, in individuals with high hepcidin levels, the activity of AS on the BASDAI and ASDAS scale was between 1.38 and 8.3 times higher than its optimal levels. It has also been found that the majority of individuals with high BASDAI and ASDAS levels is accumulatedin groups of patients with high hepcidin in particular. Our data demonstrates that CRP, IL-6, and ESR levels in serum show a strong direct correlation with hepcidin levels. It is in the group with their high levels that individuals with high levels of inflammatory markers are accumulated. 
The data obtained by us is consistent with the results of separate studies that have demonstrated a link between the level of proinflammatory mediators and disorders of hepcidin synthesis in patients with AS $[8,20]$.

Levels of serum hepcidin and prohepcidin are significantly higher in patients with inflammatory bowel disease [21], in patients with active systemic lupus erythematosus [22], and rheumatoid arthritis [23, 24]. According to [4], treatment with infliximab in patients with AS led not only to a decrease in the concentration of IL- 6 and TNF- $\alpha$, but also to a decrease in serum hepcidin levels and to reduction of anemia symptoms.

We found that in the group of patients with anemia, hepcidin levels were 1.4 times higher than in those without anemia. This was due to the accumulation of a proportion of individuals with high levels of hepcidin among individuals with anemia. Similar results were obtained in the Russian population of patients with AS, in particular in the group with anemia there was an increased level of hepcidin in $31.91 \%$ of persons, and without anemia only in $10(20 \%)$ of the examined [3] .

In the analysis of hepcidin concentration, depending on the pathogenetic variants of anemia, we found that patients with IDA had the hepcidin level practically comparable to the group of patients without anemia and / or control group. Patients with ACD were characterized by the highest levels of hepcidin.

Literature also clearly indicates that patients with ACD have significantly higher levels of hepcidin than patients with IDA [25]. In particular, RA patients with verified IDA, despite the high activity of the inflammatory process, on the contrary, showed a significant decrease in the concentration of hepcidin in the serum, which is quite comparable in terms of the role of hepcidin in iron metabolism and the desire of the body to fill its normal body of hemoglobin synthesis. Hepcidin concentration was also found to be higher in patients with normocytic and macrocytic anemia compared with the group with microcytic anemia.

Regarding the peculiarities of hematopoiesis and ferrokinetics, the connection between hepcidin and serum iron, the transferrin saturation with iron and serum ferritin was clearly traced in anemic individuals. Similar results were obtained in recent studies in RA patients [14], which established a close positive and social association of hepcidin with ferritin $(\mathrm{P}<0.001)$, while hemoglobin, serum iron, and TIBC had a negative correlation with hepcidin levels. Summarizing the above, it should be noted that the determination of serum hepcidin, the synthesis in hepatocytesof which significantly increases in the acute phase of inflammation, under the influence of proinflammatory cytokines and with iron overload, may be considered one of the leading causes of anemization of patients with inflammatory disease. Therefore, in our opinion, the disorder of iron metabolism in ACD is associated not only with the increase in the content of proinflammatory cytokines, but also with the main mediator of this condition by the level of hepcidin.

\section{CONCLUSIONS}

1. High levels of hepcidin are found in $25 \%$ of patients with AS, in $50 \%$ limit and only $25 \%$ of their optimal values. There were no high levels of hepcidin among healthy subjects, 69.2\% showed extremely high levels and $30.8 \%$ were optimal.

2. The levels of hepcidin in the serum of patients with AS are independent of the age, sex and duration of the disease, but are closely associated with the activity (levels of ESR, CRP, IL-6, BASDAI and ASDAS) of the disease. In individuals with high hepcidin levels, the activity of AS on the BASDAI and ASDAS scale was between 1.38 and 8.3 times higher than its optimal levels.

3. A close pathogenetic connection of hepcidin is established with the formation of anemic syndrome. Levels of hepcidin in patients with anemia are 1.4 times higher than in individuals without anemia. In the analysis of the concentration of hepcidin, depending on the pathogenetic variants of anemia, it was found that patients with IDA had a level of hepcidin practically comparable to the group of patients without anemia and / or control group. Patients with ACD were characterized by the highest levels of hepcidin. The ACD group with iron deficiency at hepcidin levels (48.53 $\pm 9.50 \mathrm{ng} / \mathrm{ml}$ ) occupied an intermediate position.

4. Since close associative relationships are established between hepcidin levels and inflammatory activity indicators, ferritin levels and serum iron levels, it can be considered that hepcidin plays an important role in the pathogenesis of ACD in patients with AS and can be used as a diagnostic marker for differential diagnosis IDA and ACD.

Directions of further researches are to find effective treatments for anemic syndrome in patients with AS.

\section{REFERENCES}

1. Karlova 0.G., Goryaev Yu.A.Prognozirovanie techeniya ankiloziruyushego spondiloartrita [Flow prediction of ankylosing spondyloarthritis]. Current problems of rheumatology 2002, 1. 40-43.( In Russian)

2. Nigmatyanova A.A., Fejshanova L.I., Abdrakipov R.Z., Hasanov RM. Sluchaj tyazhelogo oslozhnennogo ankiloziruyushego spondilita [A case of severe, complicated ankylosing spondylitis]. Practical medicine 2016, 2 (4(96)), 82-84. ( In Russian)

3. Shcherbakov G.I., Fomina N.V., Pavlova V.Yu. Vidy anemii i ikh svíyaz's aktivnost'yu zabolevaniya u bol'nykh s ankiloziruyushchim spondiloartritom [Types of anemia and their relationship with disease activity in patients with ankylosing spondylitis]. Organization and informatization of healthcare issue. 2016. (S), 386-388.( In Russian)

4. Braun J., Van Der Heijde D., Doyle M.K., Han C. et al. Improvement in hemoglobin levels in patients with ankylosing spondylitis treated with infliximab. Arthritis Care Res. 2009 61(8), 1032-1036. D0I 10.1002/ art.24865

5. Bulut Y., Tas D.A., Ozturk 0.G., Karaogullarindan U. Investigation of iron deficiency anemia in ankylosing spondylitis patients. Ann Rheum Dis. 2017. 6 (1), 921-922. D0I:10.1136/annrheumdis-2017-eular.5913

6. Kim K.J., Cho C.S. Anemia of chronic disease in ankylosing spondylitis: improvement following anti-TNF therapy/ankilozan spondilitte kronik anemi hastaligi/anti-TNF tedavisini takiben iyilesme. Arch Rheumatol. 2012. 27(2), 90-98. D0l: http://dx.doi.org/10.5606/tjr.2012.014 
7. Niccoli L., Nannini C., Cassara E., Kaloudi 0., Cantini F. Frequency of anemia of inflammation in patients with ankylosing spondylitis requiring anti-TNFa drugs and therapy-induced changes. Int J Rheum Dis. 2012. 15(1), 56-61. D0I: https://doi.org/10.1111/j.1756185X.2011.01662.x

8. Dagli M., Yilmaz S., Sivrikaya A., Ozturk B. Serum Prohepcidin and Hepcidin Levels in Patients with Ankylosing Spondylitis: A Prospective Study. J Clin Anal Med 2016;7(1): 38-41. D0I: 10.4328/JCAM.2451

9. Girelli D., Nemeth E., Swinkels D.W. Hepcidin in the diagnosis of iron disorders. Blood 2016, 127(23), 2809-2813. doi:10.1182/ blood-2015-12-639112

10. Pigeon C., llyin G., Courselaud B. A new mouse liver-specifi cgene, encoding a protein homologous to human antimicrobial peptide hepcidin, is over expressed during iron overload. J. Biol. Chem. 2001;276 (11): 7811-9. D0I:10.1074/jbc.M008923200

11. Poli M., Asperti M., Ruzzenenti P., Regoni M., Arosio P. Hepcidin antagonists for potential treatments of disorders with hepcidin excess. Front Pharmacol. 2014, 5, (86). doi:10.3389/fphar.2014.00086

12. D'Angelo $\mathrm{G}$. Role of hepcidin in the pathophysiology and diagnosis of anemia. Blood research 2013, 48(1), 10-15. doi:10.5045/ br.2013.48.1.10

13. Nairz M., Theurl I., Wolf D., Weiss G. Iron deficiency or anemia of inflammation? : Differential diagnosis and mechanisms of anemia of inflammation. Eisenmangel oder Entzündungsanämie? : Differenzial diagnose und Mechanismen der Entzündungsanämie. Wien Med Wochenschr 2016, 166(13-14), 411-423. doi:10.1007/s10354-0160505-7

14. KhalafW., Al-Rubaie H.A., Shihab S. Studying anemia of chronic disease and iron deficiency in patients with rheumatoid arthritis by iron status and circulating hepcidin. Hematology reports 2019, 11(1), 7708. doi:10.4081/hr.2019.7708

15. Van Der Linden S., Valkenburg H.A., Cats A. Evaluation of diagnostic criteria for ankylosing spondylitis. Arthritis Rheum. 1984. 27(4), 361368. https://doi.org/10.1002/art.1780270401

16. De Benoist B., Cogswell M., Egli I., McLean E. Worldwide prevalence of anaemia 1993-2005, 2008; WHO Global Database of anaemia.

17. Weiss G., Schett $G$. Anaemia in inflammatory rheumatic diseases. Nat Rev Rheumatol. 2013, 9(4), 205.D0I: https://doi.org/10.1038/ nrrheum.2012.183

18. Lukas C., Landewé R., Sieper J., Dougados M., Davis J., Braun $J$. et al. Assessment of SpondyloArthritis international Society. AnnRheumDis. 2009 Jan;68(1):18-24. doi: 10.1136/ard.2008.094870

19. Rheumatol J. Bath ankylosing spondylitis functional index. 1995.34(8), 793-794

20. Theurl I., Mattle V., Seifert M., Mariani M. et al. Dysregulated monocyte iron homeostasis and erythropoietin formation in patients with anemia of chronic disease. Blood 2006;107(10):4142-8. D01:10.1182/ blood-2005-08-3364

21. OustamanolakisP., KoutroubakisI.E.,Messaritakisl,,MalliarakiN.,Sfiridaki A., Kouroumalis E.A. Serum hepcidin and prohepcidin concentrations in inflammatory bowel disease. Eur J Gastroenterol Hepatol. 2011, 23(3), 262-268.doi: 10.1097/MEG.0b013e328343b885

22. Ganeb S.S., Hamad G.A., El-Tanawy R.M., Hashaad N.I. et al. Correlations between Serum prohepcidin level disease activity in rheumatoid arthritis and systemic lupus erythematous. Egyptian Rheumatology and Rehabilitation 2016, 43(3), 102. D0I: 10.4103/1110-161X.189827
23. Koca S.S., Isik A., Ustundag B., Metin K., Aksoy K. Serum pro-hepcidin levelsin rheumatoid arthritis and systemic lupus erythematosus. Inflammation 2008; 31:146-153. https://doi.org/10.1007/s10753008-9060-8

24. Kim H.R., Kim K.W., Yoon S.J., Kim S.H., Lee S.H. Serum pro-hepcidin couldreflect disease activity in patients with rheumatoid arthritis. J Korean Med Sci 2010; 25:348-352.https://doi.org/10.3346/ jkms.2010.25.3.348

25. Galushko Y.E.A. Klinicheskoye znacheniye opredeleniya gepsidina pri anemii u bol'nykh revmatoidnym artritom [The clinical significance of the determination of hepcidin in anemia in patients with rheumatoid arthritis]. Clinical Medicine 2014, 6, 21-27.( In Russian)

26. Emerah A., Abbas S.F., Pasha H.F. Serum prohepcidin concentrations in rheumatoid arthritis and its relation to disease activity. Egyptian Rheumatology and Rehabilitation, 201441(3), 130. D01: 10.4103/1110161X.140530

This study is a part of the research work "To study the role of clinical, molecular genetic, metabolic, immune-inflammatory and hemocoagulation factors in the formation of cardiovascular lesions in rheumatoid arthritis, and to develop recommendations for their prevention and treatment», the state registration number is $0113 \mathrm{U} 000670$.

\section{ORCID and contributionship:}

Sergii V. Shevchuk: 0000-0002-5649-2775 A,C,D,F

Oksana V. Zviahina: 0000-0002-1840-8288 ${ }^{A, B, C, D, E}$

Inna P. Kuvikova: 0000-0003-1891-6263 D,E

Iuliia S. Segeda: 0000-0001-8282-7703 ${ }^{D, E}$

\section{Conflict of interest:}

The Authors declare no conflict of interest.

\section{CORRESPONDING AUTHOR \\ Oksana V.Zviahina}

National Pirogov Memorial Medical University

56 Pirogov st., 21018 Vinnytsia, Ukraine

tel:+380963459619

e-mail:zviahina89@gmail.com

Received: 22.11 .2019

Accepted: 10.06 .2020

A - Work concept and design, B - Data collection and analysis, C - Responsibility for statistical analysis, D-Writing the article, $\mathbf{E}$-Critical review, $\mathbf{F}-$ Final approval of the article 